\section{Ocular syphilis: the new epidemic}

\begin{abstract}
Aim To present the clinical presentation, diagnosis, and management of syphilitic uveitis in the context of an epidemic of syphilis in the UK.

Method Retrospective clinical case series. Results Six new cases of syphilitic uveitis presented to the Manchester Uveitis Clinic in 2004, after a 15-fold increase in the incidence of syphilis in the UK, including 615 cases in Greater Manchester in the 5 years to 2004. Four cases had secondary syphilis, two had latent disease, two had no rash, and two were HIV positive. Ocular involvement included anterior or panuveitis, retinitis, retinal vasculitis, and papillitis. All resolved on treatment including intramuscular procaine penicillin $\mathrm{G}$ with oral probenecid.

Conclusions Syphilis is much more common recently and syphilitic uveitis should be considered in all patients with rash and/or headache, where there is retinitis and/or retinal vasculitis, or in any uveitis of uncertain origin. Treatment is that of neurosyphilis. Eye (2006) 20, 703-705. doi:10.1038/sj.eye.6701954; published online 3 June 2005
\end{abstract}

Keywords: syphilis; ocular syphilis; uveitis; retinitis

\section{Introduction}

Between 1998 and 2003 there was a 15-fold increase in the incidence of syphilis in the UK. In 2003,1580 cases were reported ${ }^{1}$ of which $89 \%$ were in men, and $69 \%$ were in the $25-44$ years age group. Localised outbreaks have been reported, including one in Greater Manchester. ${ }^{2}$ Between January 1999 and March 2004, 615 cases were reported in this area, of which 145 were HIV positive.

Ocular syphilis is an unusual manifestation of the disease, typically occurring during the secondary stage. Presentation is variable, but delay in treatment may result in permanent
JP Doris ${ }^{1}$, K Saha ${ }^{1}$, NP Jones ${ }^{1}$ and A Sukthankar ${ }^{2}$

visual loss in addition to other sequelae. Six confirmed cases of ocular syphilis presented to the Manchester Uveitis Clinic (MUC) in 2004 (Table 1) whereas only three cases presented during the previous 10 years. We report our clinical findings and management, and present an illustrative case report.

\section{Case report}

A 45-year-old heterosexual male (Case 1) was referred to MUC with a 1-week history of right visual loss and intermittent global headache of 3 months duration. He had a widespread maculopapular rash, also for 3 months, sparing the palms and soles, and a large painless snailtrack ulcer on the lower lip. Visual acuity was right HM, left 6/5. There was a right nongranulomatous panuveitis and a large area of retinitis above the disc extending into the posterior pole, with occlusive vasculitis and multiple satellite lesions (Figure 1). Syphilis was suspected, and serology revealed positive enzyme immunoassays, Treponemal Particle Agglutination test greater than 1:1520 and Rapid Plasma Reagent (RPR) test greater than $1: 128$, together confirming active infection. He was treated for 17 days with intramuscular procaine penicillin $\mathrm{G} 2.4 \mathrm{MU}$ and oral probenecid $500 \mathrm{mg}$ QID, with oral prednisolone commencing at $60 \mathrm{mg} /$ day. Cerebrospinal fluid was negative for syphilis serology. The headache and rash rapidly resolved on treatment, and oral steroid was tapered to zero after 10 weeks. After an initial apparent unresponsiveness there was rapid improvement in vision, recovering to $6 / 9$, with resolution of retinitis to leave widespread salt-and-pepper scarring of the RPE including the macula, and evidence of permanent vascular occlusion (Figure 2).

\section{Discussion}

Ocular syphilis, previously rare, is again merely uncommon owing to a huge rise in the incidence of syphilis in the $\mathrm{UK}^{3}{ }^{3}$ especially in
${ }^{1}$ Manchester Royal Eye Hospital, Manchester, UK

${ }^{2}$ Manchester Royal Infirmary, Manchester, UK

Correspondence: NP Jones, The Royal Eye Hospital, Oxford Road, Manchester M13 9WH, UK

Tel: + 44161276 5628;

Fax: +441612726618.

E-mail:nicholas.jones@

cmmc.nhs.uk

Received: 8 April 2005

Accepted: 23 April 2005

Published online: 3 June 2005

The authors have no proprietary or financial interest in any product, drug, instrument, or device discussed in this article 
Table 1 Clinical manifestations in six cases of ocular syphilis

\begin{tabular}{|c|c|c|c|c|c|c|c|c|}
\hline \multirow[t]{2}{*}{ Case } & \multirow{2}{*}{$\begin{array}{l}\text { Sex, age, HIV status } \\
\text { stage of syphilis }\end{array}$} & \multirow{2}{*}{$\begin{array}{l}\text { Presenting } \\
\operatorname{symptom}(s)\end{array}$} & \multirow[t]{2}{*}{ Skin signs } & \multirow[t]{2}{*}{ Uveitis } & \multicolumn{2}{|c|}{ VA pre- } & \multicolumn{2}{|c|}{ VA post- } \\
\hline & & & & & $R$ & $L$ & $R$ & $L$ \\
\hline 1 & $\begin{array}{l}\text { Male, } 45 \text { years, } \\
\text { HIV-, secondary }\end{array}$ & $\begin{array}{l}\mathrm{R} \text { DV } 1 / 52, \\
\text { headache } 3 / 12 \text {, } \\
\text { rash } 3 / 12\end{array}$ & $\begin{array}{l}\text { Generalised } \\
\text { maculopapular, } \\
\text { excluding palms/ } \\
\text { soles, lower lip } \\
\text { snail-track ulcer }\end{array}$ & $\begin{array}{l}\text { NGR R panuveitis, } \\
\text { R retinitis/ } \\
\text { vasculitis, quiescent } \\
\text { after treatment }\end{array}$ & $\mathrm{HM}$ & $6 / 6$ & $6 / 9$ & $6 / 9$ \\
\hline 2 & $\begin{array}{l}\text { Male, } 29 \text { years, } \\
\mathrm{HIV}+\text {, secondary }\end{array}$ & L DV $4 / 52$ & $\begin{array}{l}\text { Generalised } \\
\text { maculopapular, } \\
\text { including palms / } \\
\text { soles }\end{array}$ & $\begin{array}{l}\text { NGR L anterior } \\
\text { uveitis }\end{array}$ & $6 / 5$ & $6 / 6$ & \multicolumn{2}{|c|}{ defaulted } \\
\hline 3 & $\begin{array}{l}\text { Female, } 43 \text { years, } \\
\text { HIV-, late latent }\end{array}$ & $\begin{array}{l}\mathrm{R}+\mathrm{L} \text { DV 2/12, } \\
\text { pain }\end{array}$ & No & $\begin{array}{l}\text { GRA R }+\mathrm{L} \\
\text { panuveitis, } \\
\text { quiescent after } \\
\text { treatment, }\end{array}$ & $6 / 9$ & $6 / 18$ & $6 / 12$ & $6 / 9$ \\
\hline 4 & $\begin{array}{l}\text { Male, } 46 \text { years, } \\
\text { HIV +, early latent }\end{array}$ & $\begin{array}{l}\mathrm{R}+\mathrm{L} \text { blur } 2 / 52, \\
\mathrm{~L} \text { pain }\end{array}$ & Truncal zoster & $\begin{array}{l}\text { NGR R }+\mathrm{L} \text { ant } \\
\text { uveitis, RPE } \\
\text { scarring }++, \\
\text { quiescent after } \\
\text { treatment }\end{array}$ & $6 / 24$ & $6 / 60$ & $6 / 12$ & $6 / 9$ \\
\hline 5 & $\begin{array}{l}\text { Male, } 38 \text { years, } \\
\text { HIV-, secondary }\end{array}$ & $\begin{array}{l}\text { L DV } 4 / 52, \\
\text { headache } 1 / 52 \text {, } \\
\text { rash } 4 / 52\end{array}$ & $\begin{array}{l}\text { Generalised } \\
\text { maculopapular, } \\
\text { excluding palms / } \\
\text { soles }\end{array}$ & $\begin{array}{l}\text { NGR } \mathrm{R}+\mathrm{L} \\
\text { panuveitis, } \mathrm{R}+\mathrm{L} \\
\text { papillitis, } \mathrm{R} \text { focal } \\
\text { retinitis, resolving, } \\
\text { defaulted }\end{array}$ & $6 / 36$ & $6 / 9$ & $6 / 24$ & $6 / 6$ \\
\hline 6 & $\begin{array}{l}\text { Male, } 57 \text { years, } \\
\text { HIV-, secondary }\end{array}$ & $\begin{array}{l}\text { R DV } 1 / 52, \\
\text { headache 3/12, } \\
\text { rash 3/12 }\end{array}$ & $\begin{array}{l}\text { Rash on palms / } \\
\text { soles, mild } \\
\text { maculopapular } \\
\text { rash }\end{array}$ & $\begin{array}{l}\text { NGR R panuveitis } \\
\text { R retinitis/ } \\
\text { vasculitis, quiescent } \\
\text { after treatment }\end{array}$ & $\mathrm{HM}$ & $6 / 6$ & $6 / 9$ & $6 / 6$ \\
\hline
\end{tabular}

$\mathrm{DV}=$ decreased vision; VA pre- $=$ visual acuity before treatment; VA post- $=$ visual acuity after treatment; NGR $=$ nongranulomatous; GRA $=$ granulomatous.

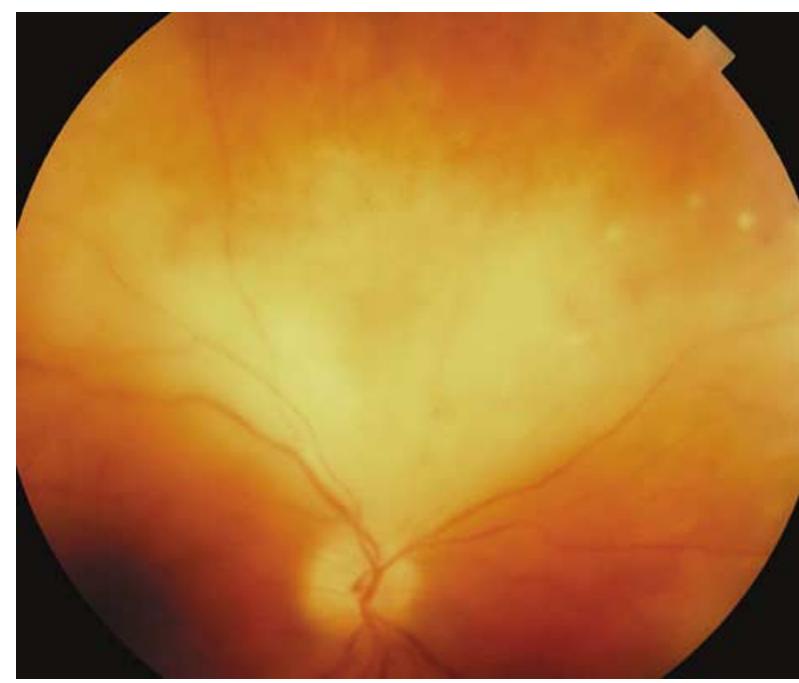

Figure 1 Case 1 on presentation: extensive retinitis above the right optic disc with multifocal satellite lesions and vascular calibre changes. Visual acuity HM.

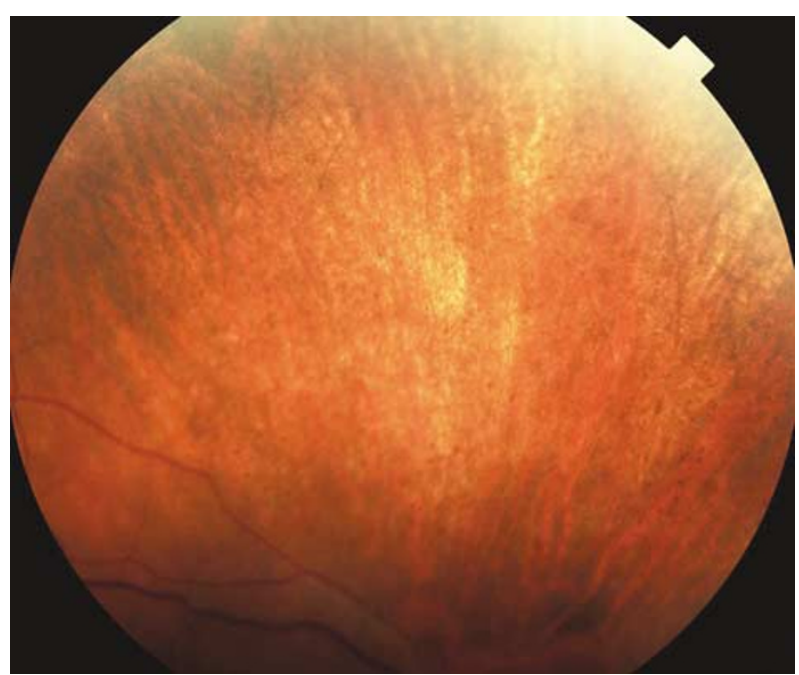

Figure 2 Case 1 after treatment: widespread mottled RPE scarring and retinal vascular occlusion. Visual acuity 6/9. 
metropolitan areas. Ocular involvement is protean: anterior uveitis may be granulomatous or nongranulomatous. Posterior segment involvement may include vitritis, retinitis, retinal vasculitis, and papillitis as seen in our patients. Neuroretinitis may occur, and placoid chorioretinitis of the macula is said to be characteristic in those who are HIV positive. ${ }^{4}$ Syphilis serology should be arranged in cases of intractable uveitis of uncertain origin, ${ }^{5}$ where there is retinitis or retinal vasculitis, and where uveitis presents with a skin rash and/or headache. Diagnosis of active syphilis requires a combination of Treponema-specific tests and nontreponemal tests. The former 'gold-standard' of FTAABS is now largely replaced by a selection of highly specific enzyme immunoassays such as syphilis ICE, and RPR provides quantitative results, helpful in judging response to treatment.

Treatment of ocular syphilis is that of neurosyphilis. ${ }^{6}$ In the UK a high-dose intramuscular regime as described above, is recommended. Despite the need for daily injection there is a high rate of compliance and efficacy. ${ }^{7}$ It has been suggested that sampling of cerebrospinal fluid (CSF) should be mandatory in those with ocular involvement, ${ }^{8}$ but as this would not change the initial treatment regime, in the absence of focal neurological signs this is open to debate. We would always pursue CSF analysis if headache is persistent despite treatment or where focal neurological signs are found.

Neurosyphilis is usually diagnosed if there are more than 20 white blood cells per microlitre of CSF in a seropositive individual, or where CSF VDRL is positive. We have used oral steroid in combination with antibiotic therapy in patients with posterior uveitis and profound visual loss; lower-dose oral steroid would be used anyway to avoid the Jarisch-Herxheimer reaction. Patients have been jointly managed by an ophthalmologist and a genitourinary physician, the latter arranging antibiotic therapy, contact tracing and treatment, counselling, and screening for concurrent infection including HIV. ${ }^{9}$ We have noted extensive RPE scarring in those recovering from syphilitic retinitis, involving a much wider area than that initially seen to be inflamed clinically. In one case, widespread RPE saltand-pepper scarring developed with no previous clinical evidence of retinitis; a degree of nyctalopia ensued (Case 4). Despite this widespread scarring, early diagnosis and treatment has resulted in substantial recovery of visual acuity in those with retinal involvement.

\section{References}

1 Anon. CDSC Sexually Transmitted Disease Quarterly Report: Syphilis in the United Kingdom. Commun Dis Rep CDR Wkly 2003; 13: 31.

2 Communicable Disease Surveillance Centre. Increased transmission of syphilis in Manchester. Commun Dis Rep CDR Wkly 2000; 10: 89.

3 Portsmann AU, Marcus U, Pleyer U. Primary diagnosis of syphilis by the ophthalmologist. Klin Monatsbl Augenheilkd 2002; 219: 349-352.

4 Gass JD, Braunstein RA, Chenoweth RG. Acute syphilitic placoid chorioretinitis. Ophthalmology 1990; 97: 1288-1297.

5 Schmidt D, Berghorn C, Weik J, Dichmann S, Vaith P. Ocular syphilis. Klin Monstbl Augenheilkd 2002; 219: 433-439.

6 Browning DJ. Posterior segment manifestations of active ocular syphilis, the response to a neurosyphilis regimen of penicillin therapy, and influence of human immunodeficiency virus status on response. Ophthalmology 2000; 107: 2015-2023.

7 Crowe G, Theodore C, Forster GE, Got BT. Acceptability and compliance with daily injections of procaine penicillin in the outpatient treatment of syphilis-treponemal infection. Sex Transm Dis 1997; 24: 127-130.

8 Ormerod LD, Puklin JE, Sobel JD. Syphilitic posterior uveitis: correlative findings and significance. Clin Infect Dis 2001; 32: 1661-1673.

9 Aldave AJ, King JA, Cunningham Jr ET. Ocular syphilis. Curr Opin Ophthalmol 2001; 12: 433-441. 